International Research Journal of Management, IT \& Social Sciences
Available online at https://sloap.org/journals/index.php/irjmis/
Vol. 6 No. 5, September 2019, pages: 261 266
$\begin{aligned} & \text { ISSN: 2395-7492 } \\ & \text { https://doi.org/10.21744/irjmis.v6n5.743 }\end{aligned}$

\title{
Effect of Capital, Manpower and Raw Materials on Production and Income of Ukir Kayu Crafts Industry
}

\author{
I Gusti Ngurah Bagus Ariputra ${ }^{a}$ \\ I Ketut Sudiana ${ }^{b}$
}

\section{Article history:}

Received: 18 March 2019

Accepted: 31 July 2019

Published: 17 September 2019

Keywords:

capital;

income;

labor;

production;

raw materials;

\begin{abstract}
The purpose of this study was to analyze the effect of capital, labor, and raw materials on production in the ukir kayu industry in Sukawati District, Gianyar Regency. The data analysis technique used in this study is path analysis. Capital, labor and raw materials directly have a positive and significant effect on production in the wood carving industry in Sukawati District, Gianyar Regency. Capital, labor, raw materials and production directly have a positive and significant effect on income in the carving woodwork industry in Sukawati District, Gianyar Regency. Capital, labor, and raw materials have an indirect effect on income through the value of production in the carving woodwork industry in Sukawati District, Gianyar Regency.
\end{abstract}

2395-7492@ Copyright 2019. The Author. This is an open-access article under the CC BY-SA license (https://creativecommons.org/licenses/by-sa/4.0/) All rights reserved.

Author correspondence:

I Gusti Ngurah Bagus Ariputra,

Faculty of Economics and Business, Udayana University, Denpasar, Indonesia.

Email address: rasumaputri80@gmail.com

\section{Introduction}

Capital contributes to increasing production growth. Increased production may reflect an increase in the production of household income (Diewert \& Fox, 2015). As for Riyanto (2001) in Herawati (2008) (in Lesmana, 2014; Aggarwal, 2017), working capital is costs incurred for company operations in one period (short term) including cash, inventory, accounts receivable, building depreciation and machine depreciation. This shows that working capital is expected to be able to accelerate the production and sales process, which in turn can quickly return capital and profits because it is used in daily production processes such as payment of employee wages, purchase of raw materials, transportation, and others (Nuryani et al., 2018; Pattiasina et al., 2019).

Labor can be affected by production and income. Cobb-Douglas theory which states that capital affects production output. This shows the higher capital will be able to increase production output, this is because in the production process requires costs that are used for labor and the purchase of raw materials and equipment (Sulistiana, 2013; Nneka et al., 2016; Putra \& Sedana, 2019). The number of workers is very influential on income, if the work user increases, the results of the production of goods will increase and affect the increase in income of the entrepreneur, and vice versa

a Udayana University, Denpasar, Indonesia

${ }^{\mathrm{b}}$ Udayana University, Denpasar, Indonesia 
when the labor used decreases or is small, then the production results obtained are few or the workmanship is not timely, resulting in entrepreneur income will decrease.

Raw materials are also an important factor affecting production and income. According to Mutiara (2010), raw materials have a high influence on production, because if raw materials are difficult to find, producers will stop the production process, and vice versa if raw materials are easy to obtain, the production process will run smoothly. The greater the number of raw materials, the greater the number of products produced, so that the greater the amount of income received from production. The raw material is the amount of material needed to carry out the production process within a certain period (Siswanta, 2011; Asa \& Sari, 2019; Gorda et al., 2018).

\section{Hypothesis}

H1: Capital, labor and raw materials directly have a positive and significant effect on production in the wood carving industry in Sukawati District, Gianyar Regency;

H2: Capital, labor, raw materials, and production directly have a positive and significant effect on income in the carving woodwork industry in Sukawati District, Gianyar Regency;

H3: Capital, labor, and raw materials have an indirect effect on income through the value of production in the wood carving industry in Sukawati District, Gianyar Regency.

\section{Materials and Methods}

This research was conducted in Sukawati District, Gianyar Regency, Bali Province. Sukawati District was chosen as a research location, because Sukawati District is one of the centers of traditional handicraft business in Bali which has become a hereditary tradition, one of which is famous for its wood carving. The industry is supported by existing raw materials so that it can be known whether capital, labor, and raw materials affect production and income in this study area. The population used is the wood carving industry in Sukawati District, Gianyar Regency. The sample in this study was the entire ukir kayu craft industry in Sukawati District, Gianyar Regency, so this study was included in the study of saturated sample populations. The research with population saturated sample method was chosen because in Sukawati District there are 100 ukir kayu craft industries. The analysis technique in this study uses path analysis.

\section{Results and Discussions}

The Effect of Capital (X1), Labor (X2), and Raw Materials (X3) on Production Value (Y1).

Table 1

Path Coefficient I

\begin{tabular}{lllll}
\hline Regression & Std. coefficient & Std. Error & $\mathrm{t}$ & Sig. \\
\hline $\mathrm{X}_{1} \rightarrow \mathrm{Y}_{1}$ & 0,217 & 0,073 & 3,211 & 0,002 \\
$\mathrm{X}_{2} \rightarrow \mathrm{Y}_{1}$ & 0,525 & 0,088 & 6,365 & 0,000 \\
$\mathrm{X}_{3} \rightarrow \mathrm{Y}_{1}$ & 0,250 & 0,030 & 2,592 & 0,011 \\
\hline
\end{tabular}

Primary Data, 2019

Information:

$X 1=$ Capital

$X 2=$ Labor

$X 3=$ Raw Material

$Y 1=$ Production Value

Based on table 1 it can be explained that the variable capital, labor, and raw materials have a positive and significant effect on the production value in the ukir kayu industry in Sukawati District, Gianyar Regency. 
The Effect of Capital (X1), Labor (X2), Raw Materials (X3) and Production Value (Y1) on Income (Y2)

Table 2

Path Coefficient

\begin{tabular}{lllll}
\hline Regression & Std. coefficient & Std. error & $T$ & Sig. \\
\hline $\mathrm{X}_{1} \rightarrow \mathrm{Y}_{2}$ & 0,431 & 0,247 & 2,959 & 0,004 \\
$\mathrm{X}_{2} \rightarrow \mathrm{Y}_{2}$ & 0,085 & 0,016 & 1,978 & 0,041 \\
$\mathrm{X}_{3} \rightarrow \mathrm{Y}_{2}$ & 0,610 & 0,088 & 3,444 & 0,001 \\
$\mathrm{Y}_{1} \rightarrow \mathrm{Y}_{2}$ & 0,134 & 0,010 & 2,021 & 0,046 \\
\hline
\end{tabular}

Primary Data, 2019

Information:

$X 1=$ Capital

$X 2=$ Labor

$X 3=$ Raw Material

$Y 1=$ Production Value

$Y 2=$ Income

Based on Table 2 it can be explained that the variable capital, raw material labor and production value have a positive and significant effect on income in the ukir kayu industry in Sukawati District, Gianyar Regency.

Table 3

Path Coefficient III

\begin{tabular}{lllll}
\hline Regression & Std. coefficient & Std. error & T & Sig. \\
\hline $\mathrm{X} 1 \rightarrow \mathrm{Y} 1$ & 0,217 & 0,073 & 3,211 & 0,002 \\
$\mathrm{X} 2 \rightarrow \mathrm{Y} 1$ & 0,525 & 0,088 & 6,365 & 0,000 \\
$\mathrm{X} 3 \rightarrow \mathrm{Y} 1$ & 0,250 & 0,030 & 2,592 & 0,011 \\
$\mathrm{X} 1 \rightarrow \mathrm{Y} 2$ & 0,431 & 0,247 & 2,959 & 0,004 \\
$\mathrm{X} 2 \rightarrow \mathrm{Y} 2$ & 0,085 & 0,016 & 1,978 & 0,041 \\
$\mathrm{X} 3 \rightarrow \mathrm{Y} 2$ & 0,610 & 0,088 & 3,444 & 0,001 \\
$\mathrm{Y} 1 \rightarrow \mathrm{Y} 2$ & 0,134 & 0,010 & 2,021 & 0,046 \\
\hline
\end{tabular}

Data Primer, 2019

$$
\begin{aligned}
& \text { Information: } \\
& X 1=\text { Capital } \\
& X 2=\text { Labor } \\
& X 3=\text { Raw Material } \\
& Y 1=\text { Production Value } \\
& Y 2=\text { Revenue }
\end{aligned}
$$

Based on Table 3 explains that the variable Capital (X1) has a positive and significant effect on Production Value (Y1), Labor (X2) has a positive and significant effect on Production Value (Y1), and Raw Materials (X3) has a positive and significant effect on Production Value (Y1). Capital variable (X1) has a positive and significant effect on income (Y2), Labor (X2) has a positive and significant effect on income (Y2), Raw Materials (X3) has a positive and significant effect on income (Y2), and production value (Y1) a positive and significant effect on income (Y2).

Ariputra, I. G. N. B., \& Sudiana, I. K. (2019). Effect of capital, manpower and raw materials on production and income of ukir kayu crafts industry. International Research Journal of Management, IT and Social Sciences, 6(5), 261-266. https://doi.org/10.21744/irjmis.v6n5.743 
Tabel 4

Direct Effect, Indirect Effect and Total Effect

\begin{tabular}{|c|c|c|c|}
\hline \multirow[b]{2}{*}{ Variable } & \multicolumn{2}{|r|}{ Effects } & \multirow{2}{*}{ Total Effect } \\
\hline & Direct & Indirect & \\
\hline $\mathrm{X} 1 \rightarrow \mathrm{Y} 1$ & 0,217 & - & 0,217 \\
\hline $\mathrm{X} 2 \rightarrow \mathrm{Y} 1$ & 0,525 & - & 0,525 \\
\hline $\mathrm{X} 3 \rightarrow \mathrm{Y} 1$ & 0,250 & - & 0,250 \\
\hline $\mathrm{X} 1 \rightarrow \mathrm{Y} 2$ & 0,431 & 0,036 & 0,467 \\
\hline $\mathrm{X} 2 \rightarrow \mathrm{Y} 2$ & 0,085 & 0,070 & 0,155 \\
\hline $\mathrm{X} 3 \rightarrow \mathrm{Y} 2$ & 0,610 & 0,033 & 0,643 \\
\hline $\mathrm{Y} 1 \rightarrow \mathrm{Y} 2$ & 0,134 & - & 0,134 \\
\hline
\end{tabular}

Primary Data, 2019

Information:

$X 1=$ Capital

$X 2=$ Labor

$X 3=$ Raw Material

$Y 1=$ Production Value

$Y 2=$ Income

Based on Table 4 shows the direct effect of variable $\mathrm{X} 1$ on variable $\mathrm{Y} 1$ is 0.217 . There is no indirect effect so the total effect is 0.217 . The direct effect of variable $\mathrm{X} 2$ on variable $\mathrm{Y} 1$ is 0.525 . There is no indirect effect so the total effect is 0.525 . The direct effect of the $\mathrm{X} 3$ variable on the $\mathrm{Y} 1$ variable is 0.250 . There is no indirect effect so the total effect is 0.250

The direct effect of variable $\mathrm{X} 1$ on variable $\mathrm{Y} 2$ is 0.431 . The indirect effect of $\mathrm{X} 1$ on the variables $\mathrm{Y} 2$ through $\mathrm{Y} 1$ is 0.036 . Therefore, the total effect of $\mathrm{X} 1$ on the variables $\mathrm{Y} 2$ through $\mathrm{Y} 1$ is 0.467 . The direct effect of the $\mathrm{X} 2$ variable on the $\mathrm{Y} 2$ variable is 0.085 . The indirect effect of $\mathrm{X} 2$ on the variables $\mathrm{Y} 2$ through $\mathrm{Y} 1$ obtained was 0.070 . Therefore, the total effect of $\mathrm{X} 2$ on the variables $\mathrm{Y} 2$ through $\mathrm{Y} 1$ is 0.155 .

The direct effect of the $\mathrm{X} 3$ variable on the $\mathrm{Y} 2$ variable was 0.610 . The indirect effect of $\mathrm{X} 2$ on the variables $\mathrm{Y} 2$ through $\mathrm{Y} 1$ is 0.033 . Therefore, the total effect of $\mathrm{X} 3$ on the variables $\mathrm{Y} 2$ through $\mathrm{Y} 1$ is 0.643 . The direct effect of the $\mathrm{Y} 1$ variable on the $\mathrm{Y} 2$ variable was 0.134 .

\section{Standard Estimated Error Value}

To find out the value of e1 which shows the number of production variable variances that are not explained by the variables Capital (X1), Labor (X2) and Raw Materials (X3) are calculated by:

$$
\begin{aligned}
& \mathrm{e}_{1}=\sqrt{\left(1-R_{1}^{2}\right)} \\
& \mathrm{e}_{1}=\sqrt{(1-0,944)} \\
& \mathrm{e}_{1}=0,329
\end{aligned}
$$

Meanwhile, to find out the value of e 2 which shows the income variable variance that is not explained by the variables Capital (X1), Labor (X2) and Raw Materials (X3) are calculated using the formula:

$$
\begin{aligned}
& \mathrm{e}_{2}=\sqrt{\left(1-R_{2}^{2}\right)} \\
& \mathrm{e}_{2}=\sqrt{(1-0,864)} \\
& \mathrm{e}_{2}=0,503
\end{aligned}
$$

\section{Model Validity Test}

To check the validity of the model, there are indicators to carry out checks, namely the coefficient of determination of the total results as follows.

$$
\begin{aligned}
& \mathrm{R}^{2} \mathrm{~m}=1-\left(\mathrm{e}_{1}\right)^{2}\left(\mathrm{e}_{2}\right)^{2} \\
& \mathrm{R}^{2} \mathrm{~m}=1-(0,329)^{2}(0,503)^{2} \\
& \mathrm{R}^{2} \mathrm{~m}=0,972
\end{aligned}
$$


Information:

$\mathrm{R}^{2} \mathrm{~m}$ : The coefficient of total determination

$\mathrm{e}_{1}, \mathrm{e}_{2}$ : Standard estimated error value

Based on the results of the calculation of the coefficient of total determination, it is found that the diversity of data that can be explained by the model is 97.2 percent or in other words the information contained in the data is 97.2 percent can be explained by the model, while the remaining 02.8 percent is explained by other variables, not in the model.

\section{Conclusion}

The results found that capital had a positive and significant effect on production in the wood carving industry in Sukawati District, Gianyar Regency. The greater the capital spent, then the production of wood carving craftsmen will be higher. The labor force has a positive and significant effect on production in the wood carving industry in Sukawati District, Gianyar Regency. The more labor productivity will increase. Raw materials have a positive and significant effect on production in the wood carving industry in Sukawati District, Gianyar Regency. The more raw materials used, the production will increase.

The results of this study also found that capital has an indirect effect on income through production in the wood carving industry in Sukawati District, Gianyar Regency. The nominal amount of capital spent will affect its income, thus indirectly the production of $u k i r$ kayu craftsmen will increase. Workers have an indirect effect on income through production in the wood carving industry in Sukawati District, Gianyar Regency. The number of workers who are adequate and contribute maximally will affect the results of their income, thereby indirectly increasing production. Raw materials have an indirect effect on income through production in the wood carving industry in Sukawati District, Gianyar Regency. More raw material expenditure will affect its income, thus indirectly the production of $u k i r$ kayu will increase.

\section{Conflict of interest statement}

The authors declared that they have no competing interest.

\section{Statement of authorship}

The authors have a responsibility for the conception and design of the study. The authors have approved the final article.

\section{Acknowledgments}

The authors would like to thank the editor of IRJMIS for their valuable time, support, and advice in completing the present research.

Ariputra, I. G. N. B., \& Sudiana, I. K. (2019). Effect of capital, manpower and raw materials on production and income of ukir kayu crafts industry. International Research Journal of Management, IT and Social Sciences, 6(5), 261-266. https://doi.org/10.21744/irjmis.v6n5.743 


\section{References}

Aggarwal, R. (2017). Different avenues of capital market (secondary market) available for investing in market of yamuna nagar. International Research Journal of Management, IT and Social Sciences, 4(3), 34-50.

Asa, M., \& Sari, M. M. R. (2019). Absorption of capital expenditure budget on regional apparatus organization in East Nusa Tenggara province. International Research Journal of Management, IT and Social Sciences, 6(5), 25-39. https://doi.org/10.21744/irjmis.v6n5.694

Diewert, W. E., \& Fox, K. J. (2015). Output growth and inflation across space and time. UNSW Business School Research Paper, (2015-04). https://doi.org/10.1111/joes.12117

Dwi Sulistiana, S. E. P. T. I. (2013). Pengaruh Jumlah Tenaga Kerja dan Modal terhadap Hasil Produksi Industri Kecil Sepatu dan Sandal di Desa Sambiroto Kecamatan Sooko Kabupaten Mojokerto. Jurnal Pendidikan Ekonomi $(J U P E), 1(3)$.

Gorda, A. O. S., Romayanti, K. N., \& Anggreswari, N. P. Y. (2018). Social capital, spiritual capital, human capital, and financial capital in the management of child welfare institutions. International Journal of Social Sciences and Humanities, 2(3), 12-20. https://doi.org/10.29332/ijssh.v2n3.183

Herawati, E. (2008). Analisis Pengaruh Faktor Produksi Modal, Bahan Baku, Tenaga Kerja dan Mesin Terhadap Produksi Glycerine Pada PT. Flora Sawita Chemindo Medan (Master's thesis).

Lesmana, E. D. Y., \& Affandi, M. (2013). Pengaruh Modal, Tenaga Kerja, Dan Lama Usaha Terhadap Produksi Kerajinan Manik-manik kaca (Studi Kasus Sentra Industri Kecil Kerajinan Manik-Manik Kaca Desa Plumbon Gambng Kec. Gudo Kab. Jombang). Jurnal Ilmiah Mahasiswa FEB, 2(2).

Mutiara, A. (2010). Analisis pengaruh bahan baku, bahan bakar dan tenaga kerja terhadap produksi tempe di kota Semarang. Semarang: Universitas Diponegoro.

Nneka, M., Anthony, K. A., \& Ann, O. (2016). Effective management of intellectual capital and organizational performance on selected manufacturing firms in Nigeria. International Research Journal of Management, IT and Social Sciences, 3(11), 22-32.

Nuryani, N. N. J., Satrawan, D. P. R., Gorda, A. A. N. O. S., \& Martini, L. K. B. (2018). Influence of human capital, social capital, economic capital towards financial performance \& corporate social responsibility. International Journal of Social Sciences and Humanities, 2(2), 65-76. https://doi.org/10.29332/ijssh.v2n2.128

Pattiasina, V., Tammubua, M. H., Numberi, A., Patiran, A., \& Temalagi, S. (2019). Capital Intensity and tax avoidance. International Journal of Social Sciences and Humanities, 3(1), 58-71. https://doi.org/10.29332/ijssh.v3n1.250

Putra, I. G. W. R., \& Sedana, I. B. P. (2019). Capital structure as a mediation variable: Profitability and liquidity on company value in real estate companies in Indonesia stock exchange. International Research Journal of Management, IT and Social Sciences, 6(4), 62-72. https://doi.org/10.21744/irjmis.v6n4.640

Riyanto, Y. (2001). Metodologi penelitian pendidikan. Surabaya: Sic, 318.

Siswanta, L. (2011). Analisis Faktor-Faktor Yang Mempengaruhi Pendapatan Pengrajin Genteng (Studi Kasus Pada Industri Kerajinan Genteng di Ceper Klaten). Jurnal Akmenika UPY, 7. 